\title{
New Pliocene localities with micromammals from the Czech Republic: a preliminary report
}

\author{
Stanislav Čermák ${ }^{*, 1}$, Jan Wagner ${ }^{* *, 2}$, Oldřich Fejfar ${ }^{* * *, 1}$ \& Ivan Horáček I***,3 $^{* *}$ \\ ${ }^{1}$ Charles University, Faculty of Science, Department of Geology and Paleontology, Albertov 6, 12843 Prague, Czech Republic \\ 2 Charles University, Faculty of Science, Department of Philosophy and History of Natural Science, Czech Republic, \\ Viničná 7, 12844 Prague, Czech Republic \\ ${ }^{3}$ Charles University, Faculty of Science, Department of Zoology, Czech Republic, Viničná 7, 12844 Prague, Czech Republic
}

Received 21 June 2006, accepted 28 July 2006

Published online 30 January 2007

With 5 figures and 2 tables

Key words: micromammals, Pliocene, Ruscinian, Villanyian, Czech Republic.

\begin{abstract}
The first well defined Pliocene mammalian faunas in the Czech Republic - found at localities Měnany 3 and Vitošov - are reported herein. Pilot samples from the localities have yielded an assemblage of at least 23 taxa of small mammals (Lipotyphla, Chiroptera, Lagomorpha, and Rodentia). The key taxa Mimomys hassiacus, M. cf. gracilis (an advanced form), Baranomys, and Germanomys in the assemblage suggest age of the fauna is Pliocene, possibly near the Ruscinian - Villanyian (MN15b MN16a) boundary.
\end{abstract}

Schlüsselwörter: Kleinsäugetiere, Pliozän, Ruscinium, Villanyium, Tschechische Republik.

\section{Zusammenfassung}

Die ersten gut definierten Säugetierfaunen des Pliozäns - aus Měňany 3 und Vitošov - werden hier zum erstenmal untersucht. Die ersten Proben lieferten eine Fauna von 23 Säugetiertaxa der Ordnungen Lipotyphla, Chiroptera, Lagomorpha und Rodentia. Die biochronologisch wichtigen Formen Mimomys hassiacus, M. cf. gracilis (eine fortschrittliche Form), Baranomys und Germanomys unterstützen die Alterseinstufung der Fauna an der Grenze des Ruscinium - Villanyium (MN15b - MN16a).

\section{Introduction}

In the past, several late Cenozoic faunas were described from the Czech Republic (Fejfar \& Horáček 1983). However, no Late Ruscinian (MN15b), or Early Villanyian (MN16a) faunal assemblage were known from that area until now. Two new localities, Měňany 3 (Central Bohemia) and Vitošov (Northern Moravia) fill this gap in the fossil record in the Czech Republic and yield new information about this rare level in Central Europe.

The following localities have been described as Late Ruscinian (MN15b) from Central Europe: Csarnóta 1-3 in Hungary (Kretzoi 1959, 1962; Jánossy 1986); Ivanovce 1 and 2 in Slovakia (Fejfar 1961a, 1961b, 1970); Węże 1 and 2 in Poland (Samsonowicz 1934; Sulimski 1959, 1962, 1964; Kowalski 1960); Gundersheim (Findling) (Fejfar \& Storch

\footnotetext{
*E-mail: stanislav.cermak@seznam.cz

** E-mail: orksos@seznam.cz

*** Corresponding author: E-mail: fejfar@natur.cuni.cz

**** E-mail: horacek@natur.cuni.cz
} 
1990), Gundersheim 4 (Tobien et al. in press), and Wölfersheim (Fejfar \& Repenning 1998; Dahlmann 2001) - all three from Germany. Changes in the composition among these faunal assemblages were identified in S-N and E-W directions (Fejfar \& Storch 1990). Slightly younger MN16a faunas are less common in this region with only a few localities known: Beremend 1-3 and 5 in Hungary (Jánossy 1986); Hajnáčka in Slovakia (Fejfar 1964; Fejfar et al. 1990; Lindsay et al. 1997; Sabol 2004a); Hambach (Mörs et al. 1998) and partly Gundersheim in Germany (Heller 1936; Fejfar \& Storch 1990). Also an important sequence of Pliocene faunas was introduced from Deutsch-Altenburg in Austria (Rabeder 1981).

\section{Material and methods}

The fossil fauna described in this paper comes from preliminary researches of the above mentioned localities. Pilot samples of sediment (about $10 \mathrm{~kg}$ from Měňany 3 and about $15 \mathrm{~kg}$ from Vitošov) were processed following conventional screen-washing procedure to recover small mammals. For purposes of this paper only taxonomically important specimens were identified (see Tables 1 and 2 for details). Measurements and drawings were made with the aid of binocular microscope. All measurements, given in millimeters, were taken on the maximum dimensions length (L) and width (W) of the occlusal surface of the teeth.

The following abbreviations were used in the text and tables: $\mathrm{c} / \mathrm{C}=$ lower/upper canine, $\mathrm{i} / \mathrm{I}=$ lower/upper incisor, $\mathrm{p} / \mathrm{P}=$ lower/upper premolar, $\mathrm{m} / \mathrm{M}=$ lower/upper molar, $\mathrm{N}$ = sample size. The dental terminology of Arvicolidae follows Rabeder (1981). The fossil material is currently held by the authors and will later be deposited in the collections of the National Museum in Prague.

\section{Survey of Měňany 3}

A limestone quarry in Plešivec Hill (= Nový Homolák Hill) contains several karstic fissures, three of

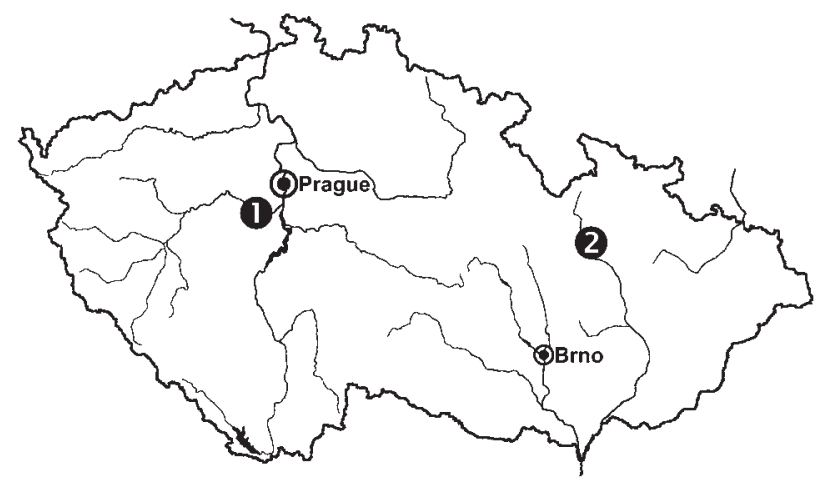

Fig 1 . The geographical position of the localities under study. 1 - Měňany 3; 2 - Vitošov.

which yielded vertebrate remains. Two of the fissures (Měňany 1 and 2) are Late Villanyian Early Biharian age. They were discovered (between 2002 and 2004) by the geologist Dr. Žák. On his advice, this quarry was visited during the fall of 2005 by several paleontologists. At that time a third fossiliferous fissure was discovered by S. Čermák and I. Horáček, and independently by C. Diedrich. Fauna from this third fissure is presented in this paper.

The site with GPS coordinates $49^{\circ} 54^{\prime} 23^{\prime \prime} \mathrm{N}$, $14^{\circ} 5^{\prime} 27^{\prime \prime} \mathrm{E}$ is located in the Bohemian Karst (Beroun District, Central Bohemia) $1.8 \mathrm{~km} \mathrm{~W}$ of the small village Měňany, within an abandoned limestone quarry in the Plešivec hill (Fig. 1).

The fossil remains are well preserved, usually whitish coloured, and, in some cases the surface of bones is covered by secondary manganese. All remains come from non-cemented terra rossa-like sediment (with secondary manganese concretions) located in the upper part of the exposure.

The age of the fauna is near the Late Ruscinian (MN15b) - Early Villanyian (MN16a) boundary (see Table 1 and "Discussion and Results" for details).

Table 1

List of identified taxa from Měňany 3 (see "Material and methods" for explanation of abbreviations).

$\begin{array}{llc}\text { Taxa } & \text { Material examined } & \text { Figures }\end{array}$

\section{Lipotyphla Haeckel, 1866}

Talpa sp. (a large form) Beremendia cf. fissidens (Petényi, 1864)

Blarinoides cf. mariae Sulimsky, 1959

Lagomorpha Brandt, 1855

Hypolagus sp.

\section{Rodentia Bowdich, 1821}

Prospalax cf. priscus Méhely, 1908 Baranomys longidens (Kowalski, 1960)

Germanomys weileri Heller, 1936

Mimomys cf gracilis (Kretzoi, 1962)

(an advanced form)

Mimomys hassiacus Heller, 1936

Synaptomys seu Lemmus sp.

\author{
1 humerus \\ $1 \mathrm{i}, 1 \mathrm{~m} 1$ \\ $1 \mathrm{i}$
}

$3 \mathrm{~A}, \mathrm{C}$

$3 \mathrm{~B}$

2 I1, 1 i1, 2 M2, 1 distal part of humerus, 1 fragment of pelvis, 1 metatarsal, 6 phalangeal bones

$1 \mathrm{M} 1, \mathrm{~L} \times \mathrm{W}=2.00 \times 1.72$

2 I

$1 \mathrm{~m} 1, \mathrm{~L} \times \mathrm{W}=1.68 \times 0.88$

$1 \mathrm{~m} 1, \mathrm{~L} \times \mathrm{W}=2.20 \times 1.12$

$3 \mathrm{~m} 1$, mean $\mathrm{L} \times \mathrm{W}=2.51 \times 1.08$;

$3 \mathrm{M} 3$, mean $\mathrm{L} \times \mathrm{W}=1.61 \times 0.89$

$3 \mathrm{~m} 1$, mean $\mathrm{L} \times \mathrm{W}=3.03 \times 1.32$

$5 \mathrm{M} 3$, mean $\mathrm{L} \times \mathrm{W}=2.04 \times 1.12$

$1 \mathrm{M} 1$
$2 \mathrm{H}$

$2 \mathrm{G}, \mathrm{g}$

$2 \mathrm{D}-\mathrm{F}, \mathrm{d}-\mathrm{f}$

$4 \mathrm{~F}, \mathrm{f}, \mathrm{G}, \mathrm{g}$

$2 \mathrm{~A}-\mathrm{C}, \mathrm{a}-\mathrm{c}$ 

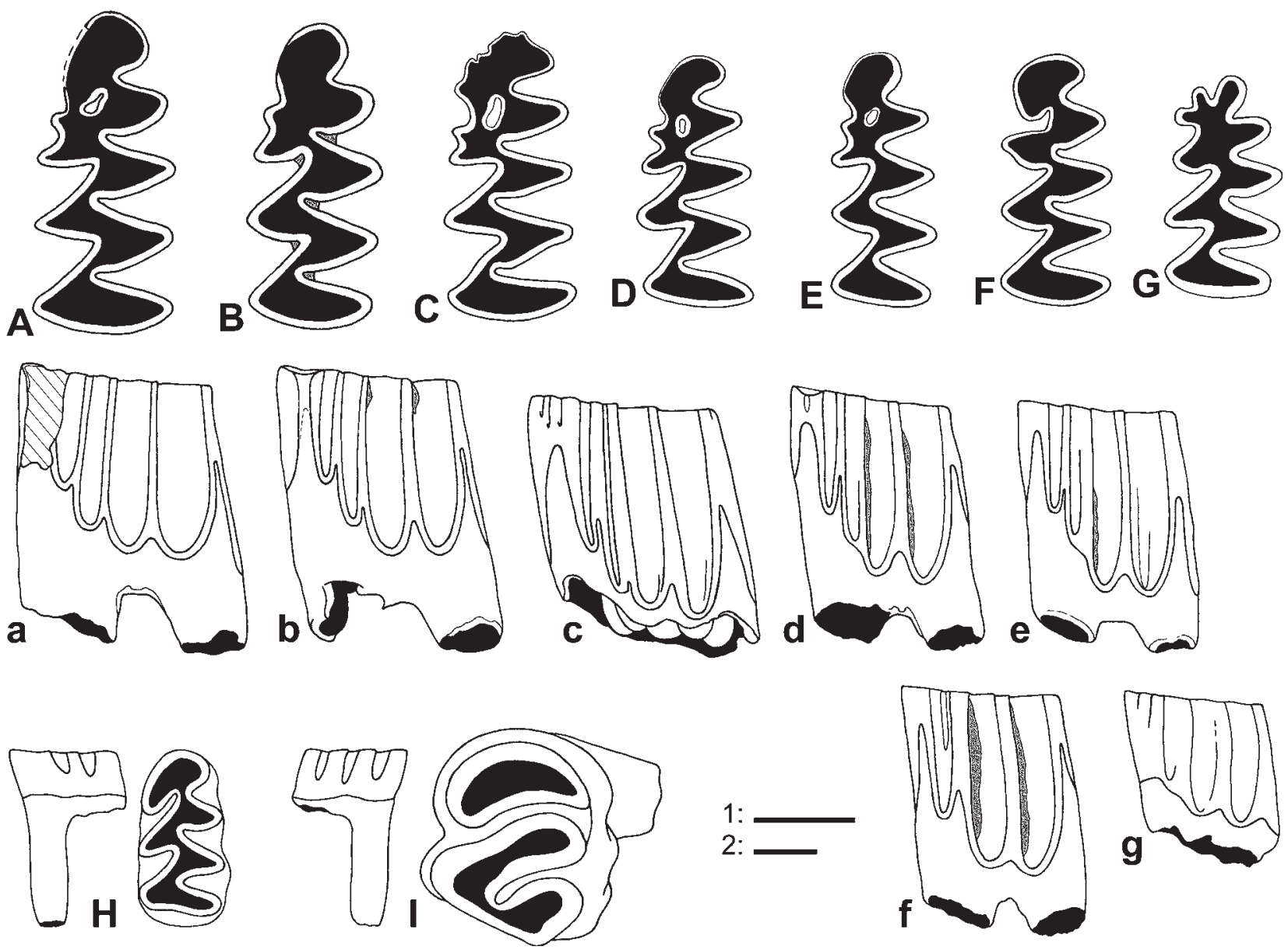

Fig. 2. Fossil remains from Měňany 3. A-C, a-c-Mimomys hassiacus Heller, 1936; A, B, a, b-m1 dex (reversed); $\mathbf{C}, \mathbf{c}-\mathrm{m} 1$ sin; D-F, d-f - Mimomys cf. gracilis Kretzoi, 1962 (an advanced form), m1 dex (reversed); G, g- Germanomys weileri Heller, 1936, m1 dex (reversed); H - Baranomys longidens Kowalski, 1960, m1 dex (reversed); I - Prospalax cf. priscus Méhely, 1908, M1 dex (reversed). A-G, I - occlusal views; $\mathbf{a}-\mathbf{g}$ - buccal views; H - buccal, occlusal, and lingual view, respectively. Scale bars represent $1 \mathrm{~mm}, \mathbf{1}$ - for occlusal view, $\mathbf{2}$ - for buccal and lingual view.

\section{Discussion of the fauna}

The cricetid remains are described in more detail since they provide the most important evidence for the age of the locality. A large and a small form of Mimomys is presented in the faunal assemblage from Měñany 3. The enamel thickness of the Mimomys teeth is not differentiated. The crown is moderately high but the crown base (linea sinuosa) is relatively low (particularly the Mimo-, Primo-, and Protosinuid). There is very thin and irregular crown-cementum in the synclines of some $\mathrm{m} 1$ (Fig. 2b, d-f). The shape of the occlusal surface of these teeth is variable, however it bears a "Mimomys"-morphotype (e.g., Mimomys-ridge, enamel islet, etc.); one $\mathrm{m} 1$ shows "Dolomys"-morphotype with an open fold (Fig. 2F), but with cementum in the synclines. The larger arvicoline specimens can be referred to Mimomys hassiacus, and the smaller one is tentatively referred to an advanced form of Mimomys gracilis (see "Discussion and Results" for details).

Germanomys is another significant member of this Late Ruscinian - Early Villanyian assemblage.
This taxon represents a conservative branch of the Arvicolinae which does not show significant changes in its primitive morphology during this time interval. The $\mathrm{m} 1$ from Měňany 3 has a low hypsodont (mesodont) crown with slight undulation of the basal enamel margin. The synclines lack cementum and the alternation of synclines is less complete. Occlusal shape of the anteroconid complex is three-lobed, the lingual lobe is longer than the buccal ones. The dimensions of $\mathrm{m} 1$ allow assignment of the specimen from Měñany 3 to Germanomys weileri. There are several insignificant differences (particularly in morphology of the anteroconid complex) among Germanomys remains from Gundersheim (type locality), Hajnáčka, Ivanovce, Ostramos 7, Rębielice Królewskie, Węże, and Wölfersheim that are probably the result of intraspecific and ontogenetic variability.

The last important cricetid member of the assemblage belongs to Baranomys, a form with the "microtoid (sensu Schaub 1934)" low prismatic structure of molars. The $\mathrm{m} 1$ from Měňany 3 is small, two-rooted, with a low crown, and almost straight basal enamel margin; the enamel is thick and less 


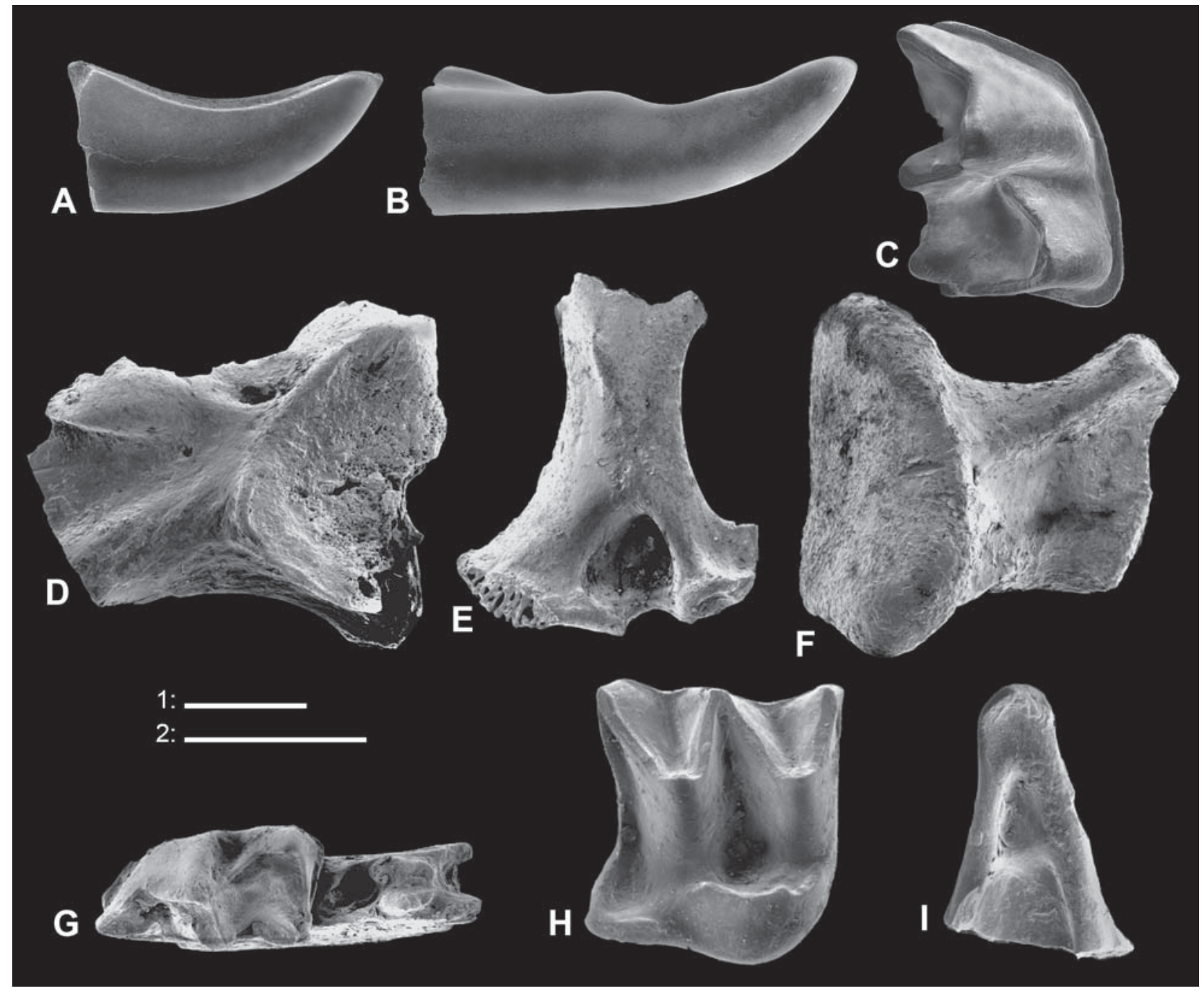

Fig. 3. Fossil remains from Měňany 3 (A-C) and Vitošov (D-I). A, C-Beremendia cf. fissidens Petényi, 1864; $\mathbf{A}-\mathrm{i}$ dex; C - m1 dex; B - Blarinoides cf. mariae Sulimsky, 1959, i dex; D - Rana sp. fragment of left illium; E - Desmanella sp., humerus; F - Talpa cf. minor Freudenberg, 1914, clavicula; G, H - Blarinella (Adelloblarinella) cf. europaea Reumer, 1984; G - m1 dex, H - M2 dex; I - cf. Sorex bor Reumer, 1984, or Paenelimnoecus pannonicus Kormos, 1934, right processus coronoideus. Scale bars represent $1 \mathrm{~mm}, \mathbf{1}$ - for $\mathbf{A}-\mathbf{F}, \mathbf{2}$ - for $\mathbf{G}-\mathbf{I}$.

differentiated; the occlusal surface is simple, consisting of rounded anteroconid and three alternating triangles. The anteroconid of $\mathrm{m} 1$ lacks an enamel islet and its labial fold is elongated; there are no dentine tracks in the synclines of the triangles. Based on the dimensions and morphology of the $\mathrm{m} 1$, this specimen is referred to Baranomys longidens, known also from the localities Gundersheim 4, Gundersheim (Findling), Węże, and Wölfersheim.

\section{Survey of Vitošov}

This site was discovered by Dr. Morávek in March 2002, when he found a vertical cave with curious pisolithic speleothemes with a small dislocated block of cemented terra near the entrance. $\mathrm{He}$ noted presence of fossils in the sample and invited us to inspect the quarry. We found the fossiliferous level during our visit in June 2002 when we obtained about $50 \mathrm{~kg}$ of the sediment.
The site with GPS coordinates $49^{\circ} 51^{\prime} 53^{\prime \prime} \mathrm{N}$, $16^{\circ} 56^{\prime} 44^{\prime \prime} \mathrm{E}$ is located $5 \mathrm{~km} \mathrm{SE}$ of the town Zábřeh (Šumperk District, Northern Moravia) within a limestone quarry near the limekiln of Vitošov (Fig. 1).

The cemented debris with terra rossa infill yielded white colored fossil remains. The content of fossils was rather poor and the material very fragmented.

The age of the fauna is near the Late Ruscinian (MN15b) - Early Villanyian (MN16a) boundary (see Table 2 and "Discussion and Results" for details).

\section{Discussion of the fauna}

Chiroptera, Gliridae, and Muridae form a dominant element of the Vitošov faunal assemblage. The presence of Desmanella sp. or Blarinella cf. 
Table 2

List of identified taxa from site of Vitošov (see "Material and methods" for explanation of abbreviations).

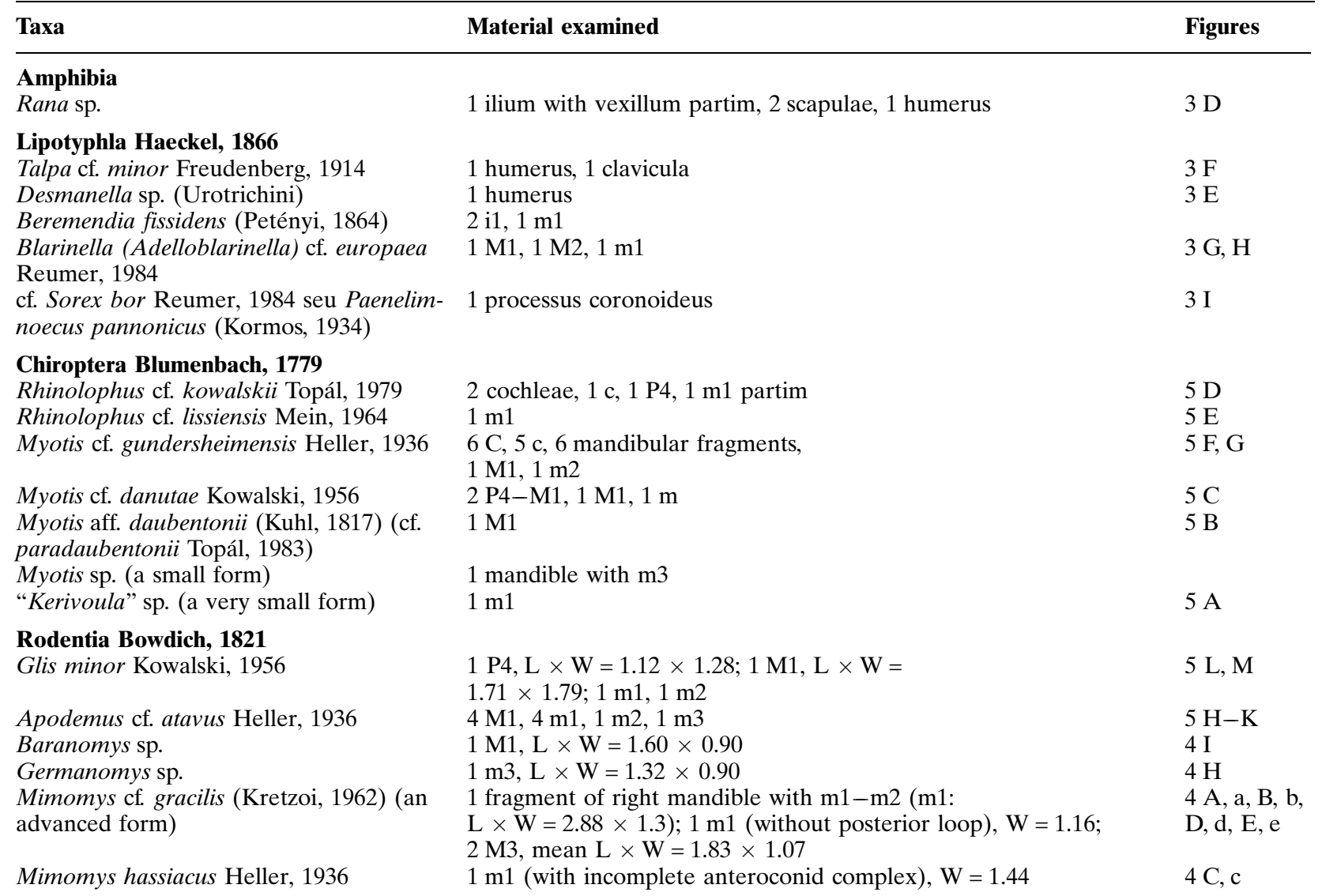
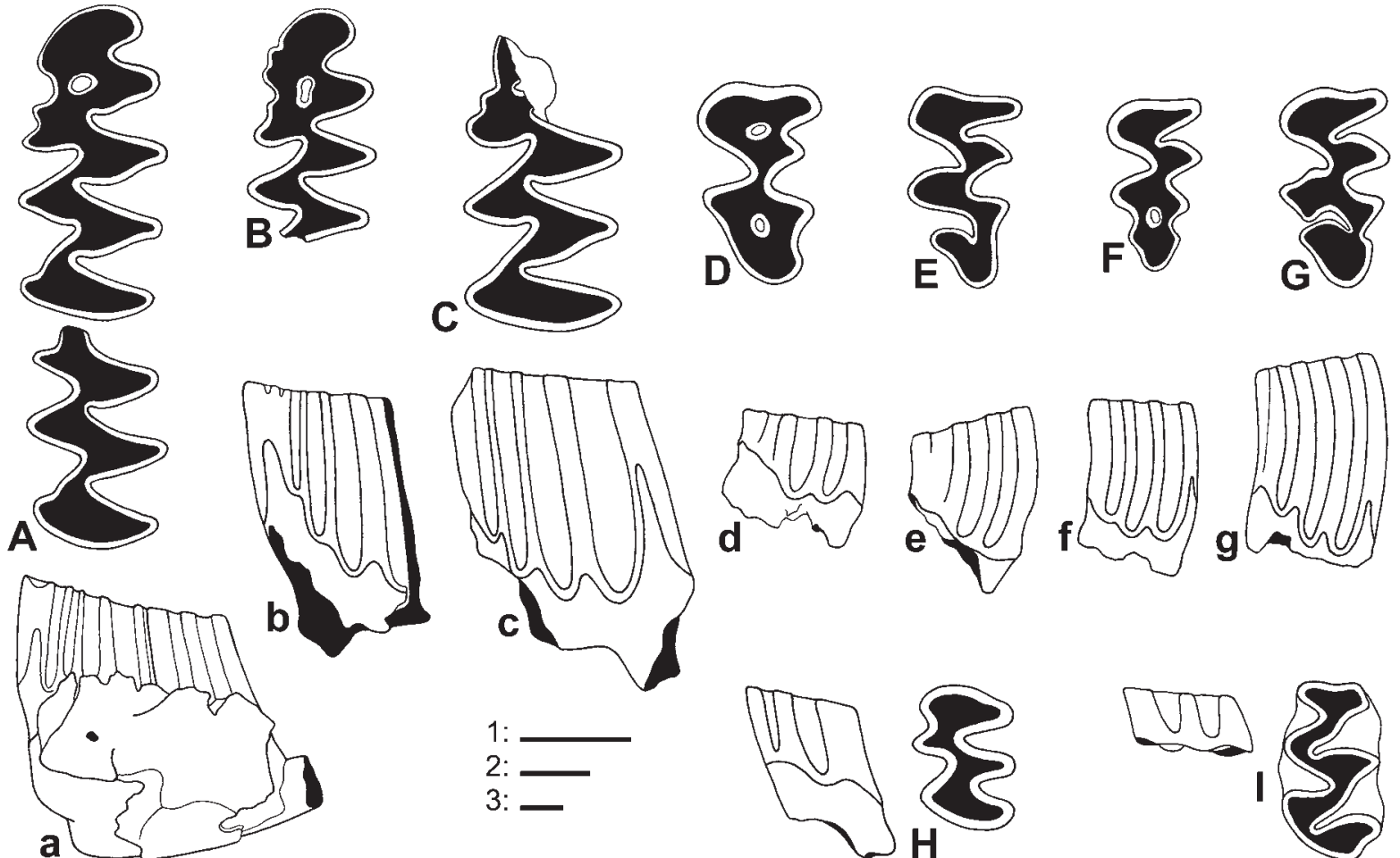

Fig. 4. Fossil remains from Vitošov ( $\mathbf{A}-\mathbf{E}, \mathbf{a}-\mathbf{e}, \mathbf{H}, \mathbf{I})$ and Měňany $3(\mathbf{F}, \mathbf{G}, \mathbf{f}, \mathbf{g})$. A, B, D, E, a, b, d, e - Mimomys cf. gracilis Kretzoi, 1962 (an advanced form); A, a - fragment of right mandible with $\mathrm{m} 1-\mathrm{m} 2$ (reversed); $\mathbf{B}, \mathbf{b}-\mathrm{m} 1 \mathrm{dex}$ (reversed); D, E, d, e - M3 sin; C, c - Mimomys hassiacus Heller, 1936, $\mathrm{m} 1$ dex (reversed); H - Germanomys sp. m3 sin; I - Baranomys sp. M1 dex (reversed); F, G, f, g-Mimomys cf. gracilis Kretzoi, 1962 (an advanced form); F, f - M3 dex (reversed); G, g- M3 $\sin$. A- $-\mathbf{G}$ - occlusal views; $\mathbf{a}-\mathbf{g}$ - buccal views; $\mathbf{H}, \mathbf{I}$ - buccal and occlusal view. Scale bars represent $1 \mathrm{~mm}, \mathbf{1}-$ for occlusal view, $\mathbf{2}$ - for buccal view, $\mathbf{3}$ - for buccal view of mandible. 


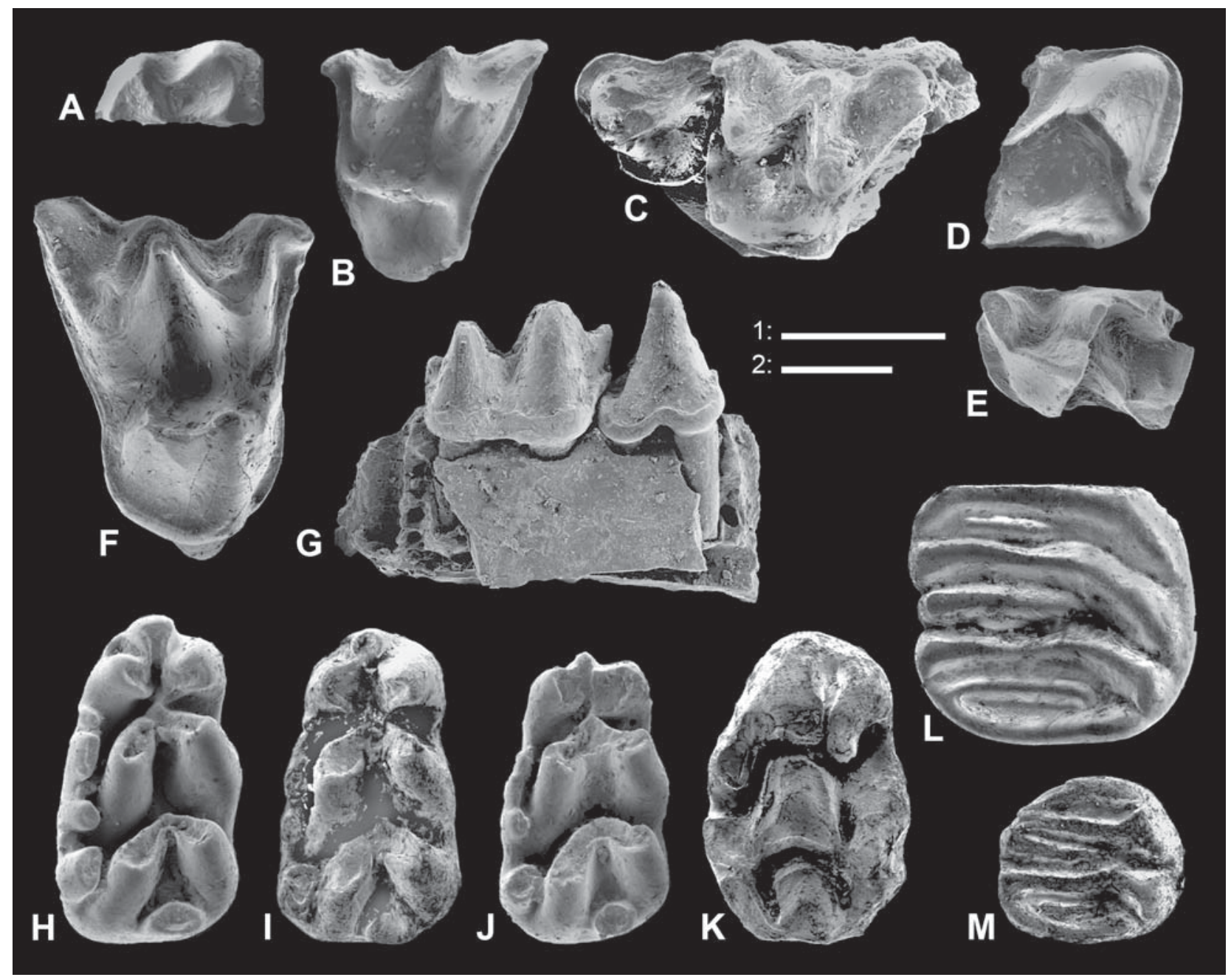

Fig. 5. Fossil remains from Vitošov. A - "Kerivoula" sp. m1 dex; B - Myotis aff. daubentonii Kuhl, 1817, M1 sin; C - Myotis cf. danutae Kowalski, 1956, P4-M1 sin; D - Rhinolophus cf. kowalskii Topál, 1979, m1 dex; E - Rhinolophus cf. lissiensis Mein, 1964, m1 sin; F, G - Myotis cf. gundersheimensis Heller, 1936; F - m2 dex; G - p4-m1 dex; H-K - Apodemus cf. atavus Heller, 1936; H-J - m1 sin; K - M1 sin; L, M - Glis minor Kowalski, 1956; L - M1 dex; M - P4 dex. Scale bars represent $1 \mathrm{~mm}, \mathbf{1}$ - for $\mathbf{A}-\mathbf{F}, \mathbf{H}-\mathbf{M}, \mathbf{2}$ - for $\mathbf{G}$.

europaea as well as a relatively high percentage of shrews in the sample support Ruscinian age for the deposit (compare Reumer 1984, 1985). A small sized myodont bat provisionally denoted "Kerivoula" resembles the material reported from MN16/17 site Javoříčko (Horáček 1988). Rhinolophus lissiensis, a gracile, medium sized horseshoe bat is reported from Lissieu (Mein 1964), Osztramos 10 (Topál 1974), Osztramos 9/1 (Jánossy \& Kordos 1977), Koněprusy - Nová propast (Horáček 1980), and a form with similar features is also present in the Gundersheim fauna (Heller 1936).

Cricetid remains are rare at Vitošov although a few specimens of Mimomys, Baranomys, and Germanomys are preserved. There are five taxonomically significant teeth which can be assigned to Mimomys species. Three $\mathrm{m} 1$ (two of them incomplete), including both a small and a large species, correspond morphologically with the $\mathrm{m} 1 \mathrm{~s}$ from Měňany 3. Two small M3 obtained from Vitošov differ in structure of the crown; in the first one the buccal and lingual dentine fields are almost confluent and there are two enamel islets on the occlusal surface; in contrast, the other M3 has only an open isle fold on the posterior loop (as in Dolomys species) and the synclines are transversely longer with more complete alternation. The enamel crown base in both upper molars is low, slightly undulated. The large molar is assigned to Mimomys hassiacus, the small molars are tentatively assigned to an advanced Mimomys gracilis. The following taxa are represented by teeth with generic features: $\mathrm{m} 3$ with thick enamel and slightly undulated basal enamel margin is asigned to Germanomys sp.; a low prismatic M1 with almost straight basal enamel margin is assigned to Baranomys sp.

The species composition and even the structure of the fauna recorded in Vitošov closely resembles the situation described from the MN15b site Gundersheim (Findling) (Fejfar \& Storch 1990; Dahlmann \& Storch 1996). 


\section{Discussion and Results}

\section{Biochronological position of the sites under study}

Most of the small mammalian taxa from Měňany 3 and Vitošov, e. g., Beremendia, Blarinoides, Talpa, Hypolagus, cover broader time ranges; however, some taxa of cricetids allow more precise correlation. For instance, Baranomys is restricted to MN14-17 zones and Germanomys is restricted to $\mathrm{MN15b}-17$ (Fejfar \& Heinrich 1990; Dahlmann 2001); so these conservative cricetids suggest an age younger than MN15a zone of the Pliocene.

The most precise biochronologic correlation is possible on the base of evolutionary stages of Mimomys species. The available teeth of large sized Mimomys from Měňany 3 and Vitošov, referred to M.hassiacus, correspond very closely, particularly in its linea sinuosa, to finds of M. hassiacus known from Gundersheim (Findling), Wölfersheim, Hambach, Beremend 3, and Hajnáčka. The material under study is almost identical with these remains and falls clearly within known species variation. In both localities described here, a small Mimomys shows the same evolutionary level of linea sinuosa of $\mathrm{m} 1$, however based on the morphology linea sinuosa of $\mathrm{M} 3$, the finds from Měňany 3 seems slightly more advanced than from Vitošov (Fig. $4 \mathrm{~d}-\mathrm{g}$ ). Taking into account the small samples, it is difficult to evaluate comparison precisely with the other known Central European sites. Nevertheless, the small Mimomys under study is slightly more advanced in the level of linea sinuosa compared with Mimomys gracilis from Csarnóta 2, Wölfersheim, Ivanovce A, and Węże; simultaneously, it seems more primitive than Mimomys stehlini from Hajnáčka and Osztramos 7. Hence, this stage of Mimomys falls within the Mimomys gracilis-stehlini lineage; most probably it belongs to an advanced form of M. gracilis.

Thus, we think that the stratigraphical position of the faunas of Měňany 3 and Vitošov based primarily on the arvicolids represent transitional assemblages between MN15b - MN16a, or possibly the earliest representatives of MN16a zone, younger than Csarnóta 2, but a little older than known Middle European MN16a faunas like Hajnáčka. That is apparent especially on the evolutionary stage of the smaller Mimomys-species, that is more advanced than typical M. gracilis (e.g., in the type locality Csarnóta 2), but without reaching the evolutionary level of $M$. stehlini from Hajnáčka. However, the paucity of the material currently available from Měňany 3 and Vitošov does not allow a precise age assignment.

\section{A note on the Pliocene chronology}

Concerning the exact chronologic position of studied faunas within the standard European time scale, several problems are noted. The two Pliocene European land mammal ages, Ruscinian and Villanyian, are defined as having a concurrent range of genera Trilophomys-Ruscinomys and Borsodia-Villanyia, respectively (Fejfar \& Heinrich 1983, 1990; Fejfar \& Horáček 1990; Fejfar et al. 1998). But in fact the Ruscinian - Villanyian boundary is for the time being less precisely definable/recognizable in the Middle European area for the following reasons: 1) in the latest faunas from the Ruscinian mammal zone (MN15b) no Ruscinomys is present; 2) the genera Villanyia and Borsodia are not currently recorded in the earliest Villanyian faunas (Hajnáčka - see Fejfar et al. 1990; Sabol 2004b; Hambach - see Mörs et al. 1998; Beremend 1-3 and 5 - see Jánossy 1986), however both of these genera are recorded in eastern Europe in the preVillanyian faunas (Fejfar \& Heinrich 1981). From the Middle European perspective, the boundary between MN15a and MN15b zones seems more precisely definable than that between $\mathrm{MN} 15 \mathrm{~b}$ and MN16a. While the MN15a - MN15b boundary is strictly characterized in the Middle Europe faunas by immigration of several new microtid genera, like Dolomys (but is sometimes, Fejfar et al. 1998, referred from MN15a), Germanomys, Stachomys, Ungaromys (Fejfar \& Heinrich 1981, 1990) and species, like Mimomys hassiacus and Dolomys occitanus (e.g. in Wölfersheim, see Fejfar \& Repenning 1998; Dahlmann 2001). No important changes are characterized for the MN15b - MN16a boundary, that is all genera of arvicolids exceed this boundary and no new genera occurred in the oldest Villanyian faunas (Fejfar \& Heinrich 1990; Dahlmann 2001).

\section{Acknowledgements}

The authors are very grateful to the Čertovy schody-Quarry Inc, in particular Ing. V. Korbel and Ing. I. Novák, and to the Vápenka Vitošov Ltd for allowing our research in the localities. We are also very grateful to the National Museum in Prague, in particular the Scientific Secretary Dr. Jiř́ Kvaček, for patronage of the research in the locality of Měñany. We wish to convey our sincere thanks to Dr. Karel Žák (Academy of Science of the Czech Republic, Institute of Geology, Prague) and Dr. Rostislav Morávek (Vlastivědné Muzeum, Olomouc) for drew our attention to the fossiliferous pocket in the quarries of Plešivec and Vitošov, respectively. Special acknowledgements go to the referees Prof. E. H. Lindsay (University of Arizona, Tucson) and Dr. Lutz Maul (Forschungsinstitut und Naturmuseum Senckenberg - Forschungsstation für Quartärpaläontologie, Weimar) for their helpful comments and language improvements of the manuscript. Last but not least, we also thank all who stood by and participated in the research. This study was partly supported by the Research Program CTS MSM 0021620845. 


\section{References}

Blumenbach, J. F. 1779. Handbuch der Naturgeschichte. J. Ch. Dietrich: 1-559.

Bowdich, T. E. 1821. An analysis of the natural, classifications of mammalia for the use of students and travellers. J. Smith: 1-115.

Brandt, J. F. 1855. Beiträge zur näheren Kenntnis der Säugetiere Russlands. Mémoires de l'Académie Imperiale des Sciences St. Pétersbourg 9: 1-365.

Dahlmann, T. 2001. Die Kleinsäuger der unterpliozänen Fundstelle Wölfersheim in der Wetterau (Mammalia: Lipotyphla, Chiroptera, Rodentia). - Courier Forschungsinstitut Senckenberg 227: 1-129.

Dahlmann, T. \& Storch, G. 1996. Eine pliozäne (ober-ruscinische) Kleinsäugerfauna aus Gundersheim, Rheinhessen. 2. Insektenfresser: Mammalia, Lipotyphla. - Senckenbergiana lethaea 76 (1/2): 181-191.

Fejfar, O. 1961a. Die plio-pleistozänen Wirbeltierfaunen von Hajnáčka und Ivanovce (Slowakei), ČSR. I. Die Fundumstände und Stratigraphie. - Neues Jahrbuch für Geologie und Paläontologie Abhandlungen 111 (3): 257-273.

- 1961b. Die plio-pleistozänen Wirbeltierfaunen von Hajnáčka und Ivanovce (Slowakei), ČSR. II. Microtidae und Cricetidae inc. sed. - Neues Jahrbuch für Geologie und Paläontologie Abhandlungen 112 (1): 48-82.

- 1964. The Lower Villafranchian Vertebrates from Hajnáčka near Filákovo in Southern Slovakia. - Rozpravy Ústředního ústavu geologického 30: 1-116.

- 1970. Die plio-pleistozänen Wirbeltierfaunen von Hajnáčka und Ivanovce (Slowakei), CSR. - VI. Cricetidae (Rodentia, Mammalia). - Mitteilungen der Bayerischen Staatssammlung für Paläontologie und Historische Geologie 10: $277-296$.

Fejfar, O. \& Heinrich, W.-D. 1981. Zur biostratigraphischen Untergliederung des kontinentalen Quartärs in Europa anhand von Arvicoliden (Rodentia, Mammalia). - Eclogae geologicae Helvetiae 74 (3): 997-1006.

- 1983. Arvicoliden-Sukzession und Biostratigraphie des Oberpliozäns und Quartärs in Europa. - Schriftenreihe für geologische Wissenschaften 19/20: 61-109.

- 1990. Proposed biostratigraphical division of the European continental Neogene and Quaternary based on Muroid rodents (Rodentia, Mammalia). In Fejfar, O. \& Heinrich, W.-D. (eds). International Symposium Evolution, Phylogeny and Biostratigraphy of Arvicolids (Rodentia, Mammalia): 115-124, Verlag Dr. Friedrich Pfeil, Munich.

Fejfar, O., Heinrich, W.-D. \& Heintz, É. 1990. Neues aus dem Villafranchium von Hajnáčka bei Filakov (Slowakei, ČSSR). - QuartŠrpalŠontologie 8: 47-70.

Fejfar, O., Heinrich, W.-D. \& Lindsay, E. H. 1998. Updating the Neogene Rodent biochronology in Europe. - Mededelingen Nederlands Instituut voor Toegepaste Geowetenschappen TNO 60: 533-554.

Fejfar, O. \& Horáček, I. 1983. Zur Entwicklung der Kleinsäugerfaunen im Villányium und Alt-Biharium auf dem Gebiet der ČSSR. - Schriftenreihe für Geologische Wissenschaften 19/20: 111-207.

- 1990. Review of fossil arvicolids (Mammalia, Rodentia) of the Pliocene and Quaternary in Czechoslovakia. In Fejfar, O. \& Heinrich, W.-D. (eds). International Symposium Evolution, Phylogeny and Biostratigraphy of Arvicolids (Rodentia, Mammalia): 125-132, Verlag Dr. Friedrich Pfeil, Munich.

Fejfar, O. \& Repenning, Ch. 1998. The ancestors of the lemmings (Lemmini, Arvicolinae, Cricetidae, Rodentia) in the early Pliocene of Wölfersheim near Frankfurt am Main; Germany. - Senckenbergiana lethaea, 77 (1/2): 161-193.

Fejfar, O. \& Storch, G. 1990. Eine pliozäne (ober-ruscinische) Kleinsäugerfauna aus Gundersheim, Rheinhessen. 1. Eine pliozäne (ober-ruscinische) Nagetiere: Mammalia, Rodentia. - Senckenbergiana lethaea 71 (1/2): 139-184

Freudenberg, W. 1914. Die Säugetiere des älteren Quartärs von Mitteleuropa, mit besonderer Berücksichtigung der Fauna von Hundsheim und Deutschaltenburg in Niederösterreich. - Geologisch-paläontologische Abhandlungen 12 (N.F.): 455-670.

Haeckel, E. 1866. Generelle Morphologie der Organismen. 2: $1-462$.

Heller, F. 1936. Eine oberpliozäne Wirbeltierfauna aus Rheinhessen. - Neues Jahrbuch für Mineralogie, Geologie und Paläontologie Abteilung B Geologie, Paläontologie 76: $99-160$.

Horáček, I. 1980. Nová paleontologická lokalita na Zlatém koni u Koněprus. - Ceský kras 20: 105-107.

- 1988. Kerivoula (Mammalia, Chiroptera), fossil in Europe? - Acta Universitatis Carolinae Geologica 1986 (2): 213-222.

Jánossy, D. 1986. Pleistocene Vertebrate Faunas of Hungary. 208 pp., Akadémiai Kaidó, Budapest.

Jánossy, D. \& Kordos, L. 1977. The tectonical and karstmorphological evolution of the Osztramos Hill based on paleontological data. - Fragmenta Mineralogica et Paleontologica 8: $39-72$.

Kormos, Th. 1934. Neue Insekternfresser, Fledermäuse und Nager aus dem Oberpliozän der Villányer Gegend. Földtáni Közlemények 64: 298-321.

Kowalski, K. 1960. Cricetidae and Microtidae from the Pliocene of Węże (Poland). - Acta zoologica cracoviensia 5 (11): 447-506.

Kretzoi, M. 1959. Insectivoren, Nagetiere und Lagomorphen der jüngstpliozänen Fauna von Csarnóta im Villányer Gebirge (Südungarn). - Vertebrata Hungarica 1 (2): $237-246$.

- 1962. Faunen und Faunenhorizont von Csarnóta. - Magyar çllami Földtani Intézet Évi Jelentése 1959: 297-395.

Lindsay, E. H., Opdyke, N. D. \& Fejfar, O. 1997. Correlation of selected late Cenozoic European mammal faunas with the magnetic polarity time scale. - Palaeogeography, Palaeoclimatology, Palaeoecology 133: 205-226.

Mein, P. 1964. Les Chiroptères (Miocene) de Lissieu (Rhone). - Comptes Rendus $89^{\text {ee }}$ Congres des Societes Savantes: 237-353.

Mörs, T., Koenigswald, W. von \& Hoch, F. von der 1998. Rodents (Mammalis) from the late Pliocene Reuver Clay of Hambach (Lower Rhine Embayment, Germany). Mededelingen Nederlands Instituut voor Toegepaste Geowetenschappen TNO 60: 135-159.

Nehring, A. 1898. Mehrere Spalax Arten. - Sitzungsberichte der Gesellschaft der Naturfreunde zu Berlin 1897: 163-183.

Petényi, S. J. 1864. A beremendi mészköbanya természetrajz é öslénytanilag leirva. - Hátrahagyott munkái: 35-81.

- 1864b. A magyországi ásatag állatok maradványainak jegyzéke. - Hátrahagyott munkái: 85-120.

Rabeder, G. 1981. Die Arvicoliden (Rodentia, Mammalia) aus dem Pliozän und dem Älteren Pleistozän von Niederösterreich. - Beiträge zur Paläontologie von Österreich 8: $1-343$.

Reumer, J. W. F. 1984. Ruscinian and early Pleistocene Soricidae (Insectivora, Mammalia) from Tegelen (The Netherlands) and Hungary. - Scripta Geologica 73: 1-173.

- 1985. The paleoecology of Soricidae (Insectivora, Mammalia) and its application to the debate on the Plio-Pleistocene boundary. - Revue de Paléobiologie 4 (2): 211-214

Sabol, M. (ed.) 2004a. Early Villanyian site of Hajnáčka I (Southern Slovakia). Paleontological research 1996-2000. 144 pp., Gemer-Malohont Museum, Rimavská Sobota.

- 2004b. 5. Rodents. In Sabol, M. (ed.). Early Villaniyan site of Hajnáčka I (Southern Slovakia). Palaeontological research 1996-2000: 53-74, Gemer-Malohont Museum, Rimavská Sobota. 
Samsonowicz, J. 1934. Zjawiska krasowe i trzeciorzędowa brekcja kostny w Wężach pod Działoszynem [Sur les phénoménes karstiques de Węże prés de Działoszyn sur la Warta]. - Z abitky Przyrody Nieżywionej Ziem Rzeczypospolitej Polskiej (3): 151-162.

Schaub, S. 1934. Über einige fossile Simplicidentaten aus China und Mongolei. - Abhandlungen der Schweizerischen paläontologischen Gesellschaft 54 (2): 1-44.

Sulimski, A. 1959. Pliocene insectivores from Węże. - Acta Paleontologica Polonica 4 (2): 119-177.

- 1962. Supplementary studies on the Insectivores from Węże I (Poland). - Acta Paleontologica Polonica 7 (3-4): 441-494.
- 1964. Pliocene Lagomorpha and Rodentia from Węże I. - Acta Paleontologica Polonica 9 (2): 149-261.

Tobien, H., Fejfar, O. \& Storch, G. in press. Gundersheim 4, a third Ruscinian micromammalian assemblage from Germany.

Topál, G. 1974. The First Record of Megaderma in Hungary (Pliocene Sediments of Osztramos. Locality 10). - Vertebrata Hungarica 15: 95-104.

- 1979. Fossil Bats of the Rhinolophus ferrumequinum Group in Hungary (Mammalia: Chiroptera) - Fragmenta Mineralogica et Palaeontologica 9: 61-101.

- 1983. New and rare fossil mouse-eared bats from the Middle Pliocene of Hungary (Mammalia) - Fragmenta Mineralogica et Palaeontologica 11: 43-54. 